\title{
Antibodies to Human Albumin in Cirrhotic Sera
}

\author{
S. Hauptman and T. B. Tomasi, Jr. \\ From the Department of Immunology, Mayo Foundation-Mayo Medical \\ School, Rochester, Minnesota 55901
}

A B S T R A C T In a previous paper we described a monoclonal IgM protein with antibody-like activity towards aggregated and native albumin. The present study was initiated to determine whether sera, other than that from patients with macroglobulinemia, contained similar antibody-like activity. It was demonstrated that approximately $40 \%$ of the sera from patients with classical Laennec's cirrhosis contained antibodies which agglutinate sheep red blood cells coated with aggregated albumin. The hemagglutinating activity was present in the void volume on Sephadex G-200 chromatography and was shown to be an immunoglobulin by its removal on passage over an anti-L-chain immunoadsorbent column. The immunoglobulin was isolated from cirrhotic sera by chromatography on an albumin immunoadsorbent column. The acid eluate from the albumin affinity column contained only $\operatorname{IgA}$. After labeling this $\operatorname{IgA}$ with ${ }^{125} \mathrm{I}$ and obtaining the $\mathrm{Fab} \alpha$ fragment by proteolysis, it was shown that the labeled Fab $\alpha$ complexed noncovalently with aggregated albumin. Complex formation between albumin and the cirrhotic IgA and Fab $\alpha$ could also be demonstrated utilizing facilitation of hemagglutination of sheep red blood cells coated with aggregated albumin. Appropriate controls consisting of normal and myeloma IgA and myeloma Fab $\alpha$ fragments failed to show evidence of complex formation with albumin. We propose that the restriction of the antibody response to the IgA class may result from the formation of antibodies against albumin altered during metabolism in the gastrointestinal tract. A possible role for antialbumin antibodies in normal albumin catabolism and in the pathogenesis of Laennec's cirrhosis is discussed.

\section{INTRODUCTION}

Monoclonal proteins with antibody-like activity toward endogenous serum protein, i.e. rheumatoid factor, have been described and are thought to be the product of aberrant clones of cells that have their representation

Received for publication 11 Jamuary 1974 and in revised form 18 February 1974. in a normal cell population (1-3). For example, the sera of elderly people frequently contain rheumatoid factor without associated disease (4), and agglutinators of red blood cells sensitized with pepsin and papaindigested IgG, have also been recognized in normal sera (5-7). These are thought to represent an antibody response to antigen-antibody complexes or to gamma globulin altered during normal metabolic processes.

In a previous communication (8) we reported a monoclonal IgM protein (L'ec) with antibody-like activity toward native and denatured albumin and suggested that this protein might be representative of an antibody which functions in some unknown manner in the normal metabolism of albumin. The present study was undertaken to determine whether an albumin antibody could be demonstrated in normal or nonmyeloma sera. Inasmuch as albumin accounts for over $50 \%$ of the protein present in normal human serum, the demonstration of this antibody might be obscured by a large antigen excess. A similar proposal has been offered for "hidden" rheumatoid factors which are saturated at the antigen-binding site by normal IgG (9). Therefore, the ideal sera to search for albumin antibodies would be those in which the serum albumin is markedly diminished, as is frequently found in Laennec's cirrhosis. This report describes the presence in cirrhotic sera of antibody-like activity, predominantly in the $\operatorname{IgA}$ class, to aggregated albumin.

\section{METHODS}

Sera. The sera used in this study were from patients who had chronic liver disease, a biopsy consistent with Laennec's cirrhosis, and a long history of alcoholic abuse. No other toxins were implicated historically and all sera were negative for hepatitis-associated antigen.

Isolation of albumin. Albumin was isolated from a single healthy normal human serum donor by techniques previously described (8). Immunoelectrophoresis and Ouchterlony analysis of this albumin preparation demonstrated a single precipitin line against three potent antiwhole normal human serum antisera and an antialbumin antiserum. Analytical ultracentrifugation revealed a single boundary and polyacrylamide gel electrophoresis (8) demonstrated a single, fast-moving band. Commercial albumin (Hoechst 
Pharmaceutical Co., Somerville, N. J.) was used in some experiments using the same isolation techniques and criteria of homogeneity as above.

Isolation of $\operatorname{IgA}$. The $\operatorname{IgA}$ fraction of cirrhotic sera which complexed with aggregated albumin was isolated as follows: whole cirrhotic serum was chromatographed on Sephadex G-200 equilibrated in $0.15 \mathrm{M} \mathrm{NaCl}$. The eluate fractions in the void volume were pooled, concentrated, and applied to an aggregated albumin immunoadsorbent column. The IgA adsorbed on the column was subsequently recovered by acid elution as desoribed below.

Affinity chromatography was carried out using cyanogen bromide-activated Sepharose 4B coupled to $800 \mathrm{mg}$ of heataggregated albumin (10). Albumin was aggregated by heating to $65^{\circ} \mathrm{C}$ for $7 \mathrm{~min}$ in $0.05 \mathrm{M}$ Tris buffer $\mathrm{pH} 8.1$. In the analytical ultracentrifuge about $30 \%$ of this preparation was monomeric (4S) albumin, while the remainder consisted of higher polymers. The aggregated albumin column was equilibrated in $0.5 \mathrm{M}$ sodium chloride and the samples were initially eluted with this buffer. The adsorbed protein was subsequently eluted with a glycine- $\mathrm{HCl}$ buffer $\mathrm{pH}$ 2.3-2.5 (acid eluate). The acid eluate was brought to neutral $\mathrm{pH}$ with $1 \mathrm{~N}$ sodium hydroxide, dialyzed against phosphate-buffered saline $\mathrm{pH} 7.2$, and concentrated by positive pressure. Only IgA was detected by Ouchterlony gel diffusion and immunoelectrophoresis employing anti-H-chain specific antisera for $\operatorname{IgG}, \operatorname{IgM}, \operatorname{IgD}$, and $\operatorname{IgE}$ as well as an antiwhole human serum antiserum. An anti-L-chain immunoadsorbent column was prepared by the same procedure from an antiserum made against normal Fab. This antiserum contained antibodies to both $\kappa$ - and $\lambda$-chains.

Preparation of radiolabeled Fab $\alpha$. Cirrhotic $\operatorname{IgA}$ obtained as described above was radiolabeled with ${ }^{125} \mathrm{I}$ according to the method of McConahey and Dixon (11). The labeled IgA was then chromatographed on Sephadex G-200 equilibrated in $0.05 \mathrm{M}$ tris- $\mathrm{HCl}$ buffer $\mathrm{pH} 8.1$ and the void volume tubes pooled, concentrated, and then dialyzed against $0.1 \mathrm{M}$ acetate buffer at $\mathrm{pH} 4.1$ for $24 \mathrm{~h}$. Pepsin (Worthington Biochemical Corp., Freehold, N. J.) was added (2\% enzyme by weight) and the digest incubated for $12 \mathrm{~h}$ at $37^{\circ} \mathrm{C}$ and then dialyzed against Tris- $\mathrm{HCl} 0.05$ $\mathrm{M} \mathrm{pH} 8.1$ to stop the reaction and to remove dialyzable peptides. The whole digest was tested in gel diffusion against a specific anti-IgA antiserum and no $F c \alpha$ reactivity was detected. The digest was shown to contain the $\mathrm{F}(\mathrm{ab})_{2} \alpha$ but not the $F a b \alpha$ or $F c \alpha$. The $F(a b)_{2} \alpha$ was reduced with $0.01 \mathrm{M}$ dithiothreitol (DTT) at $37^{\circ} \mathrm{C}$ for $1 \mathrm{~h}$ and alkylated with $0.03 \mathrm{M}$ iodoacetamide to obtain the radiolabeled Fabo fragment.

Hemagglutination. Hemagglutination was carried out by the technique of Boyden (12) with the use of tanned sheep red blood cells (SRBC) coated with heat-aggregated albumin. The titers are expressed as the reciprocal of the highest dilution demonstrating 3 or $4+$ hemagglutination. Facilitation of hemagglutination (13) was performed by incubation of twofold dilutions of cirrhotic $\operatorname{IgA}$ or Faba with aggregated albumin-coated SRBC at $37^{\circ} \mathrm{C}$ for $30 \mathrm{~min}$. After incubation each tube was washed three times in phosphate-buffered saline and resuspended in buffer. A standard amount of either specific anti-Fab or anti-Fc $\alpha$ antisera was then added and hemagglutination noted.

\section{RESULTS}

Fresh whole cirrhotic sera were examined by hemagglutination using tanned SRBC coated with aggregated albumin. As shown in Table I, 7 of 18 cirrhotic sera
TABLE I

Hemagglutination (Direct) of Cirrhotic Sera and Normal Human Serum with SRBC Coated with Aggregated Albumin

\begin{tabular}{lrr}
\hline \multicolumn{1}{c}{ Patient } & $\begin{array}{r}\text { Serum } \\
\text { titer* }\end{array}$ & $\begin{array}{r}\text { Pool I } \\
\text { titer }\end{array}$ \\
\hline 1. A. B. & 128 & 64 \\
2. M. W. & 256 & 128 \\
3. G. T. & 128 & 128 \\
4. P. S. & 128 & 64 \\
5. T. Z. & 32 & $\mathrm{ND}$ \\
6. F. G. & 32 & 32 \\
7. H. J. & 16 & 32 \\
8-18. Cirrhotic sera & 0 & $\mathrm{ND}$ \\
19-23. Normal human sera & 0 & 0 \\
\hline
\end{tabular}

* Titers are reciprocals of highest twofold dilution giving positive agglutination.

$\ddagger$ Pool I was obtained by pooling the void volume eluate from Sephadex G-200 chromatography of a cirrhotic serum (see Fig. 1 and text).

had positive hemagglutination titers ranging from 16 to 256. The controls, consisting of 5 normal human sera, 15 macroglobulinemic sera, 20 IgA myeloma sera, 2 cord sera, and 1 hypogammaglobulinemic serum were all negative. The sera with positive hemagglutination titers all had marked hypergammaglobulinemia and hypoalbuminemia. We have tested by hemagglutination 13 patients with hypergammaglobulinemia and connective tissue disease but with no associated liver disease and these sera were all negative. In addition, a small number of sera from patients with other types of liver disease, i.e. infectious mononucleosis (two), acute viral hepatitis (four), and chronic biliary cirrhosis (three), were tested and found to be negative for antialbumin antibodies.

Chromatography of a typical positive serum on Sephadex G-200 is shown in Fig. 1. When each of the

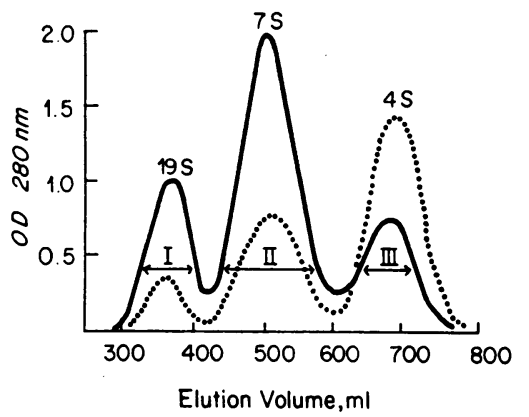

FigURE 1 Sephadex G-200 chromatograph of whole cirrhotic serum (solid line) compared to whole normal serum (dotted line) eluted with $0.14 \mathrm{M} \mathrm{NaCl}$. I, II, and III refer to pools of either fractions of normal or cirrhotic sera. The position of marker $19 \mathrm{~S}, 7 \mathrm{~S}$, and $4 \mathrm{~S}$ proteins are shown on top. 
TABLE II

Binding of Faba to Aggregated Albumin

Immunoadsorbent Column*

\begin{tabular}{lccc}
\hline Preparation & $\begin{array}{c}\text { cpm initially } \\
\text { applied }\end{array}$ & $\begin{array}{c}\text { cpm in } \\
\text { acid eluate }\end{array}$ & $\begin{array}{c}\text { Radioactivity } \\
\text { adsorbed } \ddagger\end{array}$ \\
\hline $\begin{array}{l}\text { Cirrhotic } \\
{\left[{ }^{125}\right] \text { Fab } \alpha}\end{array}$ & 29,000 & 8,500 & 43 \\
$\begin{array}{l}\text { Cirrhotic } 2 \\
{\left[{ }^{125} \mathrm{I}\right] \text { Fab } \alpha}\end{array}$ & 10,000 & 3,100 & 33 \\
$\begin{array}{l}\text { Control 1 } \\
{\left[{ }^{125} \mathrm{I}\right] \text { Fab } \alpha}\end{array}$ & 30,000 & 100 & 0.3 \\
$\begin{array}{l}\text { Control 2 } \\
{\left[{ }^{125} \mathrm{I}\right] \text { Fab } \alpha}\end{array}$ & 10,000 & 50 & 0.5 \\
\hline
\end{tabular}

* Either cirrhotic or control (myeloma) Fab $\alpha$ labeled with ${ }^{125}$ I was applied to the albumin affinity column and eluted with $0.5 \mathrm{M} \mathrm{NaCl}$ and then with glycine- $\mathrm{HCl}$ buffer at $\mathrm{pH} 2.5$. The cpm (counts per minute) initially applied to column and those recovered in the acid eluate were determined.

$\ddagger$ Percent of radioactivity adsorbed to column $=\mathrm{cpm}$ in acid eluate/cpm initially applied $\times 100$.

chromatographic pools were tested by hemagglutination, it was noted that pool I (see Fig. 1) contained significant titers while pools II and III were negative. All pools (I, II, III) of normal human serum were negative.

To determine whether hemagglutination was caused by the immunoglobulins present in the void volume, affinity chromatography was performed with an anti-L-chain immunoadsorbent column. The anti-L-chain immunoadsorbent removed all of the immunoglobulins present in pool I as determined by Ouchterlony analysis. The total protein concentration of pool I before and after immunoadsorption was made equivalent and hemagglutination performed. Before affinity chromatography the hemagglutinating titer of pool I was 256. After passage over the anti-L-chain immunoadsorbent column, all hemagglutinating activity was removed. Subsequently, the adsorbed material was eluted with acid and demonstrated a titer of 128 . The Fab of a previously reported (8) $\operatorname{IgM}$ monoclonal protein with antibody activity toward albumin was able to inhibit the hemagglutination of pool $\mathrm{I}$ at a concentration of $100 \mu \mathrm{g} / \mathrm{ml}$, whereas an $\mathrm{Fab}$ derived from an inactive IgM showed no inhibition. Furthermore, when pool I was chromatographed on an aggregated albumin immunoadsorbent column all hemagglutinating activity was removed. These findings suggest that the factor present in cirrhotic sera which complexes with aggregated albumin and gives positive hemagglutination is a high molecular weight immunoglobulin.
To identify the immunoglobulin(s) responsible for the hemagglutinating activity, pool I was subjected to affinity chromatography utilizing an aggregated albumin immunoadsorbent as described above. The acid eluates of three pool I preparations derived from different cirrhotic sera contained only IgA by gel diffusion analysis using specific antisera to all immunoglobulin classes. Controls, consisting of three different isolated monoclonal IgA preparations, two monoclonal IgM, one monoclonal IgG protein, as well as pool II, were each chromatographed over the same column. These preparations showed no significant adsorption to the column. This demonstrated the specificity of the cirrhotic IgA for aggregated albumin. As a positive control, the previously mentioned monoclonal $\operatorname{IgM}$ protein with antibody activity toward albumin was also subjected to affinity chromatography. In this case, all of the protein was adsorbed to the column.

Cirrhotic IgA obtained by acid elution from an aggregated albumin immunoadsorbent was radiolabeled with ${ }^{125} \mathrm{I}$ and digested with pepsin as described in the Methods section. The labeled Fab $\alpha$ was then analyzed for its ability to complex with albumin using the aggregated albumin-immunoadsorbent column. The results of a typical experiment are shown in Table II. The data demonstrated that with two different cirrhotic IgA 33 and $43 \%$ of the labeled $F a b \alpha$ was adsorbed to the column whereas the control $F a b \alpha$, obtained from isolated $\operatorname{IgA}$ monoclonal proteins, showed negligible binding. When the $\left[{ }^{125} \mathrm{I}\right] \mathrm{Fab} \alpha$ recovered by acid elution was rechromatographed on the same aggregated albumin column, $97.5 \%$ of the radioactivity was adsorbed (see Table III).

The specificity of cirrhotic IgA for altered albumin could also be demonstrated utilizing hemagglutination of SRBC coated with aggregated albumin. In these experiments facilitating antisera were used to enhance hemagglutination as shown in Table IV. The cirrhotic

TABLE III

Rechromatography of Acid Eluted Faba*

\begin{tabular}{lccc}
\hline \multicolumn{1}{c}{ Preparation } & $\begin{array}{c}\text { cpm initially } \\
\text { applied }\end{array}$ & $\begin{array}{c}\text { cpm in } \\
\text { acid eluate }\end{array}$ & $\begin{array}{c}\text { Radioactivity } \\
\text { adsorbed }\end{array}$ \\
\hline $\begin{array}{l}\text { Cirrhotic } \\
\text { IgA [125I]Fab } \alpha\end{array}$ & 10,000 & 9,700 & $\%$ \\
$\begin{array}{l}\text { Control } \\
\text { IgA [125 I]Fab } \alpha\end{array}$ & 11,600 & 300 & 2.5 \\
\hline
\end{tabular}

* The cirrhotic $\left[{ }^{125} \mathrm{I}\right] \mathrm{Fab} \alpha$ used in this experiment was recovered by acid elution of the aggregated albumin immunoadsorbent as shown in Table II. It was then rechromatographed on the same column and the percent of radioactivity adsorbed calculated, as described in Table II. 
TABLE IV

Facilitation of Hemagglutination*

\begin{tabular}{lcrrrr}
\hline \multicolumn{1}{c}{ Preparation } & $\begin{array}{c}\text { No faciiitating } \\
\text { antisera }\end{array}$ & anti-L & anti-IgA & anti-IgM & anti-IgG \\
\cline { 3 - 6 } Cirrhotic IgA, $200 \mu \mathrm{g} / \mathrm{ml}$ & 32 & 1,024 & 2,056 & 32 & 32 \\
Myeloma $\mathrm{IgA}, 200 \mu \mathrm{g} / \mathrm{ml}$ & 0 & 0 & 0 & 0 & 0 \\
Cirrhotic $\mathrm{Fab} \alpha, 300 \mu \mathrm{g} / \mathrm{ml}$ & 0 & 512 & 0 & 0 & 0 \\
Myeloma Fab $\alpha, 300 \mu \mathrm{g} / \mathrm{ml}$ & 0 & 0 & 0 & 0 & 0 \\
\hline
\end{tabular}

* SRBC coated with aggregated albumin and agglutination of one of the listed preparations faciliated with anti-L- or $\mathrm{H}$-chain specific antisera.

IgA obtained by acid elution from the aggregated albumin immunoadsorbent had only weak direct agglutinating activity at $200 \mu \mathrm{g} / \mathrm{ml}$. However, when an anti$\operatorname{IgA}$ antiserum was used to facilitate, the titers increased to greater than 2,000. Similarly, an anti-Lchain antiserum increased the hemagglutination titer of the cirrhotic IgA to 1,024. Appropriate controls of coated and uncoated cells with specific antisera and uncoated cells plus the acid eluate plus specific antisera were all negative. Two IgA and two IgM monoclonal proteins were also used as controls at the same concentrations as the acid eluates and there was no facilitation of hemagglutination.

The cirrhotic Fab $\alpha(300 \mu \mathrm{g} / \mathrm{ml})$, obtained by acid elution from the aggregated albumin immunoadsorbent column, was shown to be specifically bound to albumincoated SRBC by demonstrating a titer of 512 when an anti-L-chain antiserum was employed to facilitate hemagglutination. Control Fab from two IgA and two IgM monoclonal proteins at the same protein concentrations were negative, as were the controls of coated and uncoated cells with specific antisera and uncoated cells plus the acid eluate plus specific antisera.

The presence of secretory component was investigated in cirrhotic sera and isolated cirrhotic $\operatorname{IgA}$ and we were unable to demonstrate it in any of these preparations.

Although this was a retrospective study, some information can be gleaned from the clinical data. The seven patients demonstrating significant antibody titers tended to have more severe manifestations of chronic liver disease, i.e., jaundice, ascites, and edema. In this regard all of the patients with both antialbumin antibody titers and severe liver disease were shown to have marked hypergammaglobulinemia and hypoalbuminemia on protein electrophoresis. The 11 patients with negative titers had a mean albumin concentration of $3.3 \mathrm{~g} / 100 \mathrm{ml}$ (normal range $3.0-4.0 \mathrm{~g} / 100 \mathrm{ml}$ ) (patient range 2.8-3.9 $\mathrm{g} / 100 \mathrm{ml}$ ) with a mean gamma globulin concentration of $2.2 \mathrm{~g} / 100 \mathrm{ml}$ (normal range 0.94-2.1 g/100 ml) (patient range 1.9-2.6 g/100 ml). The seven patients with positive titers had a mean albumin concentration of $2.0 \mathrm{~g} / 100 \mathrm{ml}$ and a mean gamma globulin concentration of $4.2 \mathrm{~g} / 100 \mathrm{ml}$. In spite of these overall relationships, there was no direct correlation between the height of the antibody titer and the degree of hypoalbuminemia and/or hypergammaglobulinemia.

\section{DISCUSSION}

In this study, antibody-like activity against altered albumin was demonstrated in cirrhotic sera. All positive sera had a marked polyclonal elevation of immunoglobulins and diminished albumin. Chromatography of positive sera on Sephadex G-200 demonstrated that the hemagglutinating activity for aggregated albumin was restricted to the void volume pool. By selectively depleting this pool of immunoglobulins, employing an anti-L-chain immunoadsorbent column, it was established that immunoglobulins were responsible for the activity. Utilizing an aggregated albumin immunoadsorbent column it was shown that only IgA was bound to the column and this could be recovered by acid elution. The $\operatorname{IgA}$ isolated by this method and the Fab $\alpha$ derived from it by pepsin proteolysis, could be shown by several techniques (facilitated hemagglutination and the adsorbence of $\left[{ }^{205} \mathrm{I}\right] \mathrm{Fab} \alpha$ to aggregated albumin columns) to complex with aggregated albumin.

No attempt was made in this study to determine whether the cirrhotic IgA complexed with native as opposed to altered albumin. However, the occurrence of positive titers in whole cirrhotic sera containing about $3 \mathrm{~g} / 100 \mathrm{ml}$ of albumin suggested that inhibition by native monomer (4S) albumin occurs only at high albumin concentrations if at all. This was also found in a previous study (8), where concentrations of monomer albumin above $50 \mathrm{mg} / \mathrm{ml}$ were necessary to inhibit hemagglutination of SRBC coated with aggre- 
gated albumin by a monoclonal IgM protein having antibody-like activity toward albumin.

Although the cirrhotic Faba was shown to be selectively removed by the aggregated albumin immunoadsorbent column, only 43 and $33 \%$ were absorbed from the two preparations on the first passage over the column. The observation that significantly less than $100 \%$ adsorption occurred may be explained by some loss in activity caused by the acid elution, or by iodination of the original IgA. Also, since the pepsin digest of the labeled IgA was not fractionated after digestion, there may have been present nondialyzable labeled fragments derived from the Fc. After recovering the adsorbed $F a b \alpha$, a second passage over the same affinity column resulted in nearly $100 \%$ adsorption as shown in Table III.

The reason for the antibody response to altered albumin and its selective occurrence in the $\operatorname{IgA}$ class is unknown. Since a significant portion of serum IgA may be synthesized by plasma cells in the lamina propria of the small intestine (14), it is possible that the albumin reactive $\operatorname{Ig} \mathrm{A}$ found in cirrhotic sera originates in the gastrointestinal tract. In this regard, it has been clearly established that albumin is present on the mucosal surface of the intestinal tract and the gut is thought to be a major site of albumin catabolism in man (15-17). In addition, there are changes in bacterial flora and enzyme content of the gastrointestinal fluid in cirrhosis (18) that may lead to excessive and/or an altered albumin catabolism. Thus, albumin altered in the course of normal or abnormal (cirrhotic) metabolism may serve as a source of local gastrointestinal immunization, producing antibodies limited to the IgA class. This is consistent with the restriction of albumin reactive $\operatorname{IgA}$ to the Sephadex void volume of cirrhotic sera. Gut IgA is synthesized predominantly as a dimer and would chromatograph close to the void volume. An additional factor in determining chromatographic position may be the presence of complexes of IgA and monomer albumin. The albumin antibodies could also arise at least in part, from immunocytes located in the liver. Hadziyannis, Feizi, Scheuer, and Sherlock (19) have reported that $\operatorname{IgA}$-containing cells were the predominant cell type in alcoholic cirrhosis and most other liver diseases with the exception of primary biliary cirrhosis in which the majority of cells were IgM. Moreover, these workers found that when large numbers of cells of a certain immunoglobulin type were present in the liver, the respective serum immunoglobulin level was almost always elevated.

Another possibility, admittedly speculative, is that alcohol itself not only causes toxic injury to the liver resulting in decreased albumin synthesis but also structurally alters the final product. Albumin could also be altered locally in the gastrointestinal tract by continuing high concentrations of alcohol. The altered albumin might then serve as the immunizing agent either in the liver and/or gastrointestinal tract resulting in an antibody that reacts with heat-aggregated albumin and cross-reacts with normal serum albumin although the latter point was not investigated in this study.

It is interesting to speculate on the possible biological effects of the antialbumin antibodies. The antibody could alter the synthesis and/or catabolism of albumin. There is precedence for an effect of antibody on both synthesis (20) and catabolism (21) of proteins. It is also conceivable that immune complexes containing altered albumin or the development of delayed hypersensitivity to albumin might perpetuate liver damage initiated by alcohol. The question of whether immune complexes of IgA and albumin and/or whether cellular immunity to albumin is present in cirrhotics is currently being investigated.

The coexistence of severe liver disease with hypergammaglobulinemia and hypoalbuminemia could be positively correlated with the presence of antibodies to aggregated human albumin. Although this might support the argument of antibodies having a role in the pathogenesis of chronic liver disease, it is also possible that this is a secondary phenomenon and that patients with more severe liver disease tend to develop these antibodies late in their clinical course and they have little significance in the pathogenesis of the disease. A prospective study is needed to clarify this point. Although we were unable to demonstrate albumin antibodies in nine patients with liver diseases other than alcoholic cirrhosis, no definite conclusions concerning specificity of these antibodies for Laennec's cirrhosis can be drawn. A larger study of various liver disease sera, including chronic active hepatitis, is needed to answer this question.

\section{ACKNOWLEDGMENTS}

This investigation was supported in part by U. S. Public Health Service Research Grant AM 17554 from the National Institute of Arthritis and Metabolic Diseases.

\section{REFERENCES}

1. Metzger, H. 1967. Characterization of a human macroglobulin. V. A Waldenstrom macroglobulin with antibody activity. Proc. Natl. Acad. Sci. U. S. A. $57: 1490$ 1497.

2. Kritzman, J., H. Kunkel, J. McCarthy, and R. C. Mellors. 1961. Studies of a Waldenström-type macroglobulin with rheumatoid factor properties. J. Lab. Clin. Med. 57 : 905-917.

3. Solomon, A., and H. G. Kunkel. 1967. A "monoclonal" type, low molecular weight protein related to $\gamma \mathrm{M}$ macroglobulins. Am. J. Med. 42: 958-968.

4. Heimer, R., F. M. Levin, and E. Rudd. 1963. Globulins resembling rheumatoid factor in serum of the aged. Am. J. Med. 35: 175-181. 
5. Osterland, C. K., M. Harboe, and H. G. Kunkel. 1963. Anti- $\gamma$-globulin factors in human sera revealed by enzymatic splitting of anti-Rh antibodies. Vox Sang. 8: 133-152.

6. Waller, M., N. Curry, and J. Mallory. 1968. Immunochemical and serological studies of enzymatically fractionated human IgG globulins -1. Immunochemistry. 5: 577-583.

7. Lawrence, T. G., Jr., and R. C. Williams, Jr. 1967. Studies of human anti- $\gamma$-globulin factors reacting with pepsin-digested $\gamma$-globulins. J. Exp. Med. 125: 233-248.

8. Hauptman, S., and T. B. Tomasi, Jr. 1974. A monoclonal IgM protein with antibody-like activity for human albumin. J. Clin. Invest. 53: 932-940.

9. Allen, J. C., and H. G. Kunkel. 1966. Hidden rheumatoid factors with specificity for native $\boldsymbol{\gamma}$ globulins. Arthritis Rheum. 9: 758-768.

10. Mannik, M., and D. E. Stage. 1971. Antibody-agarose immunoadsorbents : complete removal of classes of immunoglobulins from serum. J. Immunol. 106: 1670-1672.

11. McConahey, P. J., and F. J. Dixon. 1966. A method of trace iodination of proteins for immunological studies. Int. Arch. Allergy Appl. Immunol. 29: 185-189.

12. Boyden, S. V. 1951. The adsorption of proteins on erythrocytes treated with tannic acid and the subsequent hemagglutination by antiprotein sera. J. Exp. Med. 93: 107-120.

13. Fudenberg, H., W. J. Mandy, and A. Nisnoff. 1962.
Serological studies of proteolytic fragments of rabbit agglutinating antibodies. J. Clin. Invest. 41: 2123-2134.

14. Vaerman, J. P., and J. P. Heremans. 1970. Origin and molecular size of immunoglobulin-A in the mesenteric lymph of the dog. Immunology. 18: 27-38.

15. Horowitz, M. I., and F. Hollander. 1961. Serum proteins in anacid gastric mucinous secretions. J. Biol. Chem. 236: 770-773.

16. Jeffries, G. H., H. R. Holman, and M. H. Sleisenger. 1962. Plasma proteins and the gastrointestinal tract. $N$. Engl. J. Med. 266: 652-660.

17. Rothschild, M. A., M. Oratz, and S. S. Schreiber. 1973. Albumin metabolism. Gastroenterology. 64: 324-337.

18. Gorbach, S. L., D. Lal, and R. Levitan. 1970. Intestinal microflora in Laennec's cirrhosis. J. Clin. Invest. 49: 36a. (Abstr.)

19. Hadziyannis, S., T. Feizi, P. H. Scheuer, and S. Sherlock. 1969. Immunoglobulin-containing cells in the liver. Clin. Exp. Immunol. 5: 499-514.

20. Murgita, R. A., C. A. Mattioli, and T. B. Tomasi, Jr. 1973. Production of a runting syndrome and selective I $\gamma \mathrm{A}$ deficiency in mice by the administration of antiheavy chain antisera. J. Exp. Med. 138: 209-228.

21. Waldman, T. A., J. S. Johnson, and N. Talal. 1971. Hypogammaglobulinemia associated with accelerated catabolism of IgG secondary to its interaction with an IgG-reactive monoclonal IgM. J. Clin. Invest. 50: 951-959. 